\title{
Heavy Metals Concentration in Mullet Fish, Liza $a b u$ from Petrochemical Waste Receiving Creeks, Musa Estuary (Persian Gulf)
}

\author{
Alireza Safahieh, Fazel Abdolahpur Monikh*, Ahmad Savari, Abdolmajid Doraghi \\ Department of Marine Biology, Faculty of Marine Science, Marine Science and Technology University, Khorramshahr, Iran. \\ Email: *Fazel_abdolahpur2@yahoo.com
}

Received June 21 ${ }^{\text {st }}, 2011$; revised August 23 ${ }^{\text {rd }}, 2011$; accepted September $28^{\text {th }}, 2011$.

\begin{abstract}
Fish in estuaries, especially those live near petrochemical area, may be exposed to various kinds of contaminants such as heavy metals. This study was to investigate the variations of heavy metals in Liza abu from the Musa estuary which receives petrochemical wastes. Fish samples were obtained from five different creeks. The samples were dissected into liver, gill and muscle, acid digested and their heavy metals level were analyzed. The results showed that the concentration of $\mathrm{Cd}, \mathrm{Co}, \mathrm{Cu}, \mathrm{Ni}$ and $\mathrm{Pb}$ in muscle ranged 0.08-0.44, $\mathrm{ND}-1.63,0.89-4.28,0.48-2.73$ and $0.5-2.50(\mu \mathrm{g} / \mathrm{g}) \mathrm{re}-$ spectively. Their concentrations in liver were $0.44-2.03,0.5-2.80,5.05-36.22,0.48-4.91$ and $0.66-5.74(\mu \mathrm{g} / \mathrm{g})$ respectively. The concentration of these metals in gill was $0.32-2.72,0.29-1.10,4.33-6.03,4.61-17.52$ and 2.64 $21.41(\mu \mathrm{g} / \mathrm{g})$ respectively. Generally, the level of heavy metals in muscle tissue of Liza abu was lower than the general standard.
\end{abstract}

Keywords: Wastewater, Khor-Jafari, Khor-Ghazale, Liver, Muscle

\section{Introduction}

Fish occupies a particular position in the aquatic contamination studies, because it play significant roles in establishing water equality guidelines and is considered as a main part of human diet [1,2]. The nutritional benefits of fish might be related to essential proteins, vitamin and two kinds of potential healthful omega-3 polyunsaturated fatty acids (PUFA); docosahexaenoic acid (DHA, is found most abundantly in brain and retina) and eicosapentaenoic acid (EPA, exists profusely in nervous system) [3-5]. Nevertheless, fish is influenced by various types of contaminants such as heavy metals, PAHs and PCBs and subsequently could be changed into a main source of contaminant uptake for human being. Industries, agriculture activities and transportation are potential sources of toxic contaminants in the marine environment [6-8].

Heavy metals constitute a highlighted group of pollutants in aquatic ecosystems because of their accumulative behavior $[9,10]$. Since they are not biodegradable, they could enter aquatic food chain $[11,12]$ and consequently accumulate in organisms positioned in various trophic levels. This condition may also produce health problem in people who consume contaminated seafood [13]. For example, they may appear in threatening form for children and women [14]. They cause neurological damages [15], increase the risk of cancer and increase the risk of abortion in pregnant woman [16]. The transferring of heavy metals from mother to fetus through placenta is another kind of threat rises from excess consumption of heavy metals by human [16]. These harmful peculiarities of heavy metals can turn fish consumption into an environmental mishap. Physicochemical factors of seawater $(\mathrm{pH}$, salinity, temperature and suspended matters) [17], as well as ecological and biological factors (weight, size, age, sex, species and season) determine the accumulation of metals in fish [18]. However, metal toxicity via contaminated fish is mainly dependent upon metal speciation [19] quantity of consumed fishes and age of consumer [20].

Musa Estuary, one of the largest estuaries in the Persian Gulf, is located in the northwest of the Gulf. It has subtropical climate with tow marked seasons including winter and summer. This estuary consists of many branches and creeks, which each creek is locally called Khor. Thus, it provides a suitable habitat for fish, shrimp and 
other economically important aquatic organisms. Mullet fish is one of the most abundant fish species in Musa Estuary, which is caught all over the year in the area. Due to its low price, it constitutes a major part the local people diet. Despite it particular position in people diet the available data on heavy metal accumulation by this species is scarce. Musa Estuary is also an industrialized estuary, around which many small industries and the biggest Iranian petrochemical complex has been developed, the risk of marine contamination by various contaminants such as heavy metals in this ecosystem is an expected issue. Fish that grow in such area could be a potential source of heavy metals intake for human consumers especially when it is frequently consumed. The objective of present study was in order to establish new information about heavy metals level in L.abu as well as determine potential risk for human consumers. The study also provides useful data as a baseline for future monitoring studies concerning heavy metals contamination in the area.

\section{Materials and Methods}

\subsection{Sampling and Sample Preparation}

Fish samples were collected from five different stations Including, Khor-Ghazale, Khor-Ahmadi, Khor-Jafari, Khor-Zangi and Khor-Ghanam (Figure 1) using gillnet during September and February 2009. Ten individuals with the same size $(16-18 \mathrm{~cm})$ of Mult, L. abu were obtained from each Khor, transferred to the laboratory using icebox and were kept frozen at $-20^{\circ} \mathrm{C}$ until dissec- tion. Before analysis, the samples were thawed at room temperature. Each sample was dissected for its muscle, the entire liver and gill tissues. The tissues were oven dried at $80^{\circ} \mathrm{C}$ for $24 \mathrm{~h}$. About 1 gram of dried tissues was digested in concentrated nitric acid (65\% Merck). The remaining digested solution was made up to certain volume with double distilled water and filtered through $0.42 \mu \mathrm{m}$ paper filter.

\subsection{Apparatus}

A GBC (Savant AA $\sum$, Australia) Flame Atomic Absorption Spectrometer was employed to determine $\mathrm{Cd}, \mathrm{Co}$, $\mathrm{Cu}, \mathrm{Ni}$ and $\mathrm{Pb}$ in samples. All the studied metals were determined with air-acetylen flame. The operation conditions are given in Table $\mathbf{1}$.

\subsection{Reagents}

All reagents used were of analytical grade. Concentrated stock solution of $1000 \mathrm{mg} / \mathrm{l}$ (merck, Germany) of each metal was diluted by double distilled water for instrument calibration. All the glassware were soaked in $10 \%$ nitric acid for $24 \mathrm{~h}$ and rinsed three times with double distilled water before use. Standard reference material (Dorm-2, muscle of Dogfish, National Research Council of Canada) was used to check the analysis accuracy. The result showed good agreement with the certified values. The recovery values were; $107 \%, 103 \%, 94 \%, 112 \%$ and $98 \%$ for $\mathrm{Cd}, \mathrm{Co}, \mathrm{Cu}, \mathrm{Ni}$ and $\mathrm{Pb}$ respectively. The blanks were prepared in a similar manner without samples to avoid samples contamination. The prepared blanks were

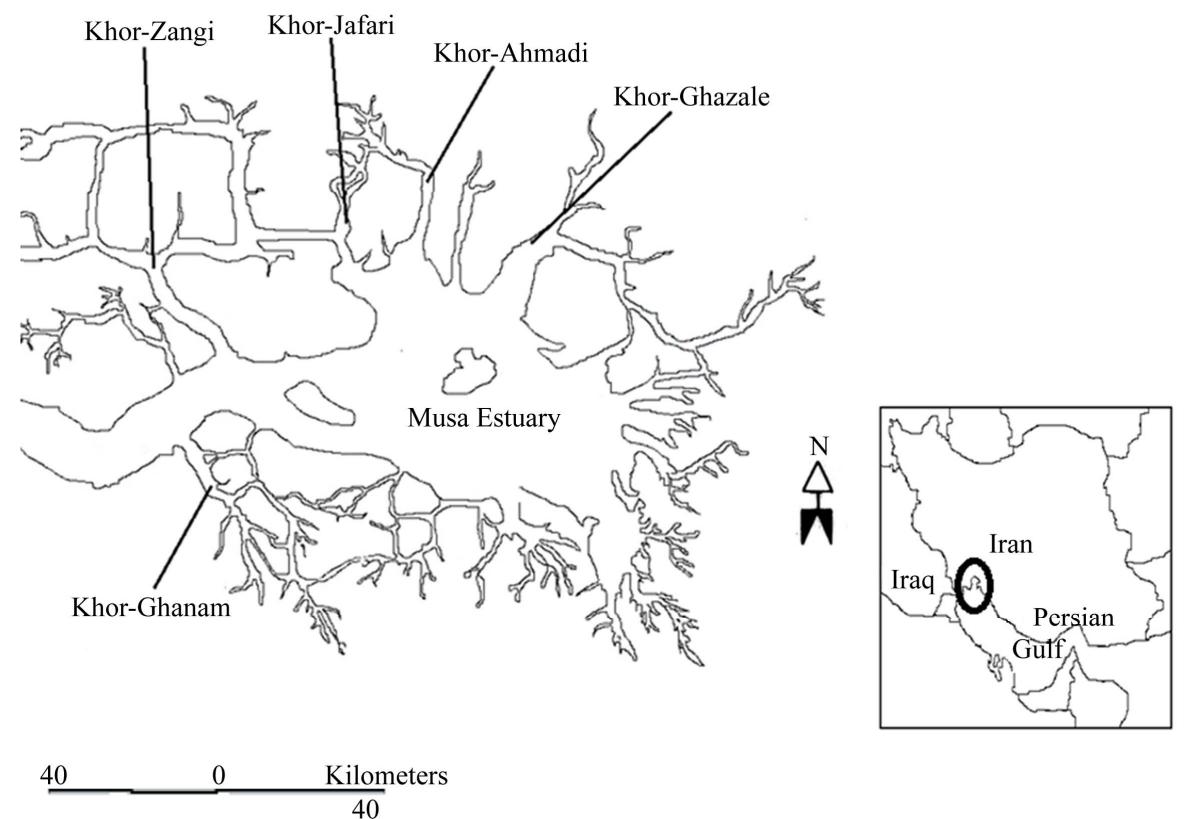

Figure 1. Location of the sampling stations. 
Table 1. The operation condition of the AAS.

\begin{tabular}{cccccc}
\hline & $\mathrm{Cd}$ & $\mathrm{Co}$ & $\mathrm{Cu}$ & $\mathrm{Ni}$ & $\mathrm{Pb}$ \\
\hline Wavelengh (nm) & 228.8 & 240.7 & 324.7 & 232 & 217 \\
Silt Width (nm) & 0.05 & 0.2 & 0.5 & 0.2 & 1 \\
Lamp Current (MA) & 3 & 6 & 3 & 4 & 5 \\
\hline
\end{tabular}

used to calibrate the instrument. They also routinely were analyzed after every 10 analysis in order to auto zero of the AAS.

\subsection{Statistical Analysis}

All data were tested for normal distribution with Shapirowilk normality test. Significant differences between heavy metals concentration in the samples of various stations were determined using One-Way analysis of variance (ANOVA) fallowed by Duncan post hoc test. Seasonal differences in metal concentration were examined using $\mathrm{t}$ _test. The level of significance was set at $\alpha=0.05$.

\section{Results and Discussion}

The concentration of $\mathrm{Cd}, \mathrm{Co}, \mathrm{Cu}, \mathrm{Ni}$ and $\mathrm{Pb}$ (mean \pm standard error) in the liver tissue of L. $a b u$ is shown in Table 2. The maximum concentration of Co $(2.80 \mu \mathrm{g} / \mathrm{g})$, $\mathrm{Cu}(36.22 \mu \mathrm{g} / \mathrm{g})$ and $\mathrm{Ni}(4.91 \mu \mathrm{g} / \mathrm{g})$ were observed in the liver tissue of fish from Khor-Jafari. The maximum concentration of $\mathrm{Cd}(2.03 \mu \mathrm{g} / \mathrm{g})$ and $\mathrm{Pb}(5.74 \mu \mathrm{g} / \mathrm{g})$ were obtained in the fish from Khor-Ghanam and Khor-Zangi respectively. The results of heavy metal analysis in the muscle are presented in Table 3. The concentration of Co in muscle tissue was below the detection limit in summer. The highest concentration of $\mathrm{Cd}(0.35 \mu \mathrm{g} / \mathrm{g})$ and $\mathrm{Pb}(2.54 \mu \mathrm{g} / \mathrm{g})$ were obtained in the muscle of fish from Khor-Ghanam and Khor-Jafari respectively. The highest concentration of $\mathrm{Co}(1.63 \mu \mathrm{g} / \mathrm{g}), \mathrm{Cu}(4.28 \mu \mathrm{g} / \mathrm{g})$ and $\mathrm{Ni}(2.73 \mu \mathrm{g} / \mathrm{g})$ were found in the muscle tissue belong to fish from Khor-Zangi. The concentration of heavy metals detected in the gill samples has given in Table 4. The highest concentration of $\mathrm{Cd}(2.72 \mu \mathrm{g} / \mathrm{g})$ and Co $(1.10 \mu \mathrm{g} / \mathrm{g})$ were noted in Khor-Jafari, while the maximum of $\mathrm{Cu}(6.03 \mu \mathrm{g} / \mathrm{g}), \mathrm{Ni}(17.52 \mu \mathrm{g} / \mathrm{g})$ and $\mathrm{Pb}$ $(21.41 \mu \mathrm{g} / \mathrm{g})$ were detected in the gill tissue belong to fish from Khor-Ahmadi, Khor-Ghazale and Khor-Zangi respectively.

\subsection{Inter-Station Distribution of Heavy Metal}

Khor-Jafari and Khor-Zangi originate from Musa Estuary and are stretched along PETZONE (Petrochemical Special Economic Zone) up to Mashahr and Sarbandar cities. These creeks are used as municipal wastes receptors. Moreover, they receive copious amount of petrochemical wastewater along their courses. Thus, the higher level of accumulated metals in fish from Khor-Jafari and Khor-Zangi could be related to anthropogenic activities and effluent discharges into the mentioned Khors. The proximity of Khor-Ghazale to oil terminal turns this area into a waterway for oil tankers. Therefore, the enrichment of heavy metals in this creek might reflect oil pollution in the area. Khor-Ahmadi is located between Khor-Jafari and Ghazale and consequently a great amount of heavy metal may displace to this creek by movements produced by waves and tidal current $[21,22]$.

\subsection{Differences of Metals Accumulation among Season}

Heavy metals accumulate in muscle, liver and gills displayed significant variation among different seasons $(\mathrm{p}<$ 0.05 ). Significant seasonal differences for heavy metal accumulation in the liver, gill and muscle are given in Tables 2, 3 and 4 respectively. There was a clear seasonal resemblance between concentration of $\mathrm{Cd}$ in the liver, muscle and gill and concentration of $\mathrm{Co}, \mathrm{Cu}$ and $\mathrm{Ni}$ in the gills, except in the few cases. Generally the results showed that the concentration of Co in the liver and gill, $\mathrm{Cu}$ in the liver and muscle and $\mathrm{Pb}$ in the gills during winter were higher than summer. On the other hand, Ni concentration in the liver and muscle during summer was significantly higher than winter in all Khors. Seasonal variations observed in the metals concentration could be attributed to the differences in local pollution, bioavailability of metals (variations among physiochemical factors) and fish metabolism (growth cycle, reproduction and feeding) [23-25]. In addition, some other indirect activities such as energy demand activities, atmospheric deposition and runoff inputting, that could lead to metal contamination, are variable among seasons. The spawning period of $L . a b u$ takes place in winter (January and February). During this period, the feeding habits of $L$. $a b u$ might get altered [26]. This alteration in feeding habits could be the reason of observed difference in metal concentrations between the seasons [27].

Mullet fish is known as Phytoplanktivores (diatoms) and detritus feeder [28]. Due to decrease of Phytoplankton productivity during winter, the fish tends to leave surface waters and goes down near the sediment and here it mainly feeds on detritus. It is known that sediment is a main sink of contaminants particularly heavy metals en- 
Table 2. Heavy metal concentration in the liver in summer and winter.

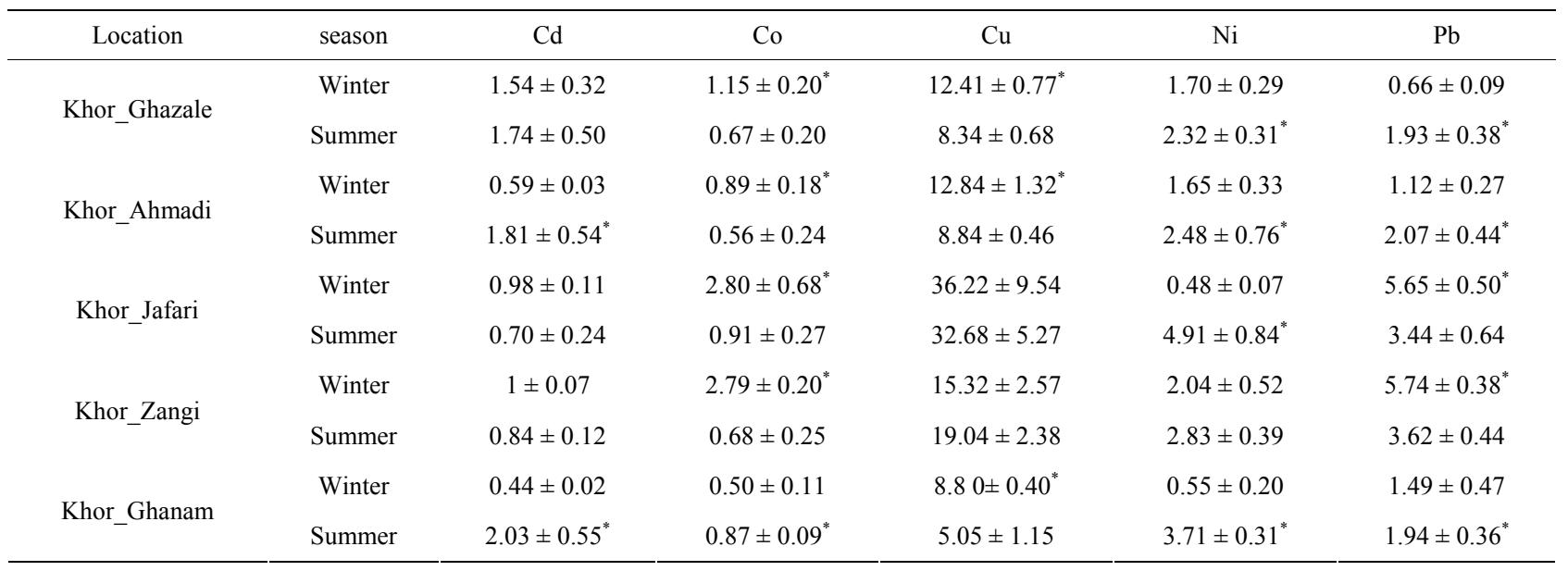

* Shows significant difference between seasons.

Table 3. Heavy metal concentration in the muscle in summer and winter.

\begin{tabular}{|c|c|c|c|c|c|c|}
\hline Location & season & $\mathrm{Cd}$ & $\mathrm{Co}$ & $\mathrm{Cu}$ & $\mathrm{Ni}$ & $\mathrm{Pb}$ \\
\hline \multirow{2}{*}{ Khor-Ghazale } & Winter & $0.08 \pm 0.03$ & $1.28 \pm 0.16$ & $1.49 \pm 0.17^{*}$ & $1 \pm 0.36$ & $0.50 \pm 0.17$ \\
\hline & Summer & $0.14 \pm 0.05$ & ND & $0.89 \pm 0.10$ & $2.14 \pm 0.40^{*}$ & $1.55 \pm 0.33^{*}$ \\
\hline \multirow{2}{*}{ Khor-Ahmadi } & Winter & $0.44 \pm 0.12$ & $0.51 \pm 0.25$ & $2.66 \pm 0.14^{*}$ & $0.48 \pm 0.14$ & $1.72 \pm 0.63$ \\
\hline & Summer & $0.21 \pm 0.05$ & ND & $1.18 \pm 0.32$ & $2.18 \pm 0.30^{*}$ & $1.76 \pm 0.27$ \\
\hline Khor-Jafari & Summer & $0.20 \pm 0.03$ & ND & $1.73 \pm 0.45$ & $1.89 \pm 0.27^{*}$ & $2.54 \pm 0.49^{*}$ \\
\hline \multirow{2}{*}{ Khor-Zangi } & Winter & $0.32 \pm 0.06$ & $1.63 \pm 0.22$ & $4.28 \pm 0.35^{*}$ & $0.80 \pm 0.21$ & $2.50 \pm 0.57$ \\
\hline & Summer & $0.11 \pm 0.02$ & ND & $1.47 \pm 0.08$ & $2.73 \pm 0.32^{*}$ & $1.74 \pm 0.66$ \\
\hline Khor-Ghanam & Winter & $0.35 \pm 0.05$ & $0.38 \pm 0.13$ & $2.72 \pm 0.37^{*}$ & $0.71 \pm 0.21$ & $0.70 \pm 0.17$ \\
\hline
\end{tabular}

$\mathrm{ND}=$ Not Detected. ${ }^{*}$ Shows significant difference between seasons.

Table 4. Heavy metal concentration in the gill in summer and winter.

\begin{tabular}{|c|c|c|c|c|c|c|}
\hline Location & season & $\mathrm{Cd}$ & $\mathrm{Co}$ & $\mathrm{Cu}$ & $\mathrm{Ni}$ & $\mathrm{Pb}$ \\
\hline \multirow{2}{*}{ Khor-Ghazale } & Winter & $0.96 \pm 0.24$ & $1.05 \pm 0.09$ & $4.84 \pm 0.24$ & $13.59 \pm 0.72$ & $11.30 \pm 0.85$ \\
\hline & Summer & $1.02 \pm 0.09$ & $0.52 \pm 0.04$ & $5.1 \pm 0.30$ & $17.52 \pm 1.02^{*}$ & $9.41 \pm 0.93$ \\
\hline \multirow{2}{*}{ Khor-Ahmadi } & Winter & $1.1 \pm 0.08$ & $0.50 \pm 0.04$ & $6.03 \pm 0.10$ & $10.03 \pm 0.99$ & $4.69 \pm 0.24$ \\
\hline & Summer & $0.94 \pm 0.05$ & $0.47 \pm 0.03$ & $5.83 \pm 0.14$ & $13.10 \pm 0.98$ & $4 \pm 0.41$ \\
\hline Khor-Jafari & Summer & $2.68 \pm 0.37$ & $0.53 \pm 0.10$ & $5.52 \pm 0.13$ & $13.21 \pm 0.96$ & $5.32 \pm 0.81$ \\
\hline \multirow{2}{*}{ Khor-Zangi } & Winter & $1.14 \pm 0.21$ & $0.77 \pm 0.06$ & $4.92 \pm 0.57$ & $4.61 \pm 1.02$ & $21.41 \pm 1.18^{*}$ \\
\hline & Summer & $1 \pm 0.08$ & $0.37 \pm 0.05$ & $5.04 \pm 0.50$ & $6.02 \pm 0.84$ & $17.31 \pm 1.21$ \\
\hline Khor-Ghanam & Winter & $0.32 \pm 0.08$ & $0.40 \pm 0.05$ & $4.33 \pm 0.20$ & $4.84 \pm 0.68$ & $3.10 \pm 0.24$ \\
\hline
\end{tabular}

* Shows significant difference between seasons. 
tered aquatic ecosystem [29,30]. Therefore, concentration of some metals in the fish tissues may rise in winter relative to summer.

\subsection{Comparison between Tissues}

Generally, metals concentration in the muscle tissue was lower compared to liver and gills (Figure 2). Many authors have reported that metal accumulation by liver and gills occur in higher magnitude than muscle [31]. Metal accumulation in each tissue considerably depends upon the accumulation capacity of the tissue [32-34]. Liver is well as a target organ for storage and detoxification of the excess heavy metals uptaken by fish [35-37].

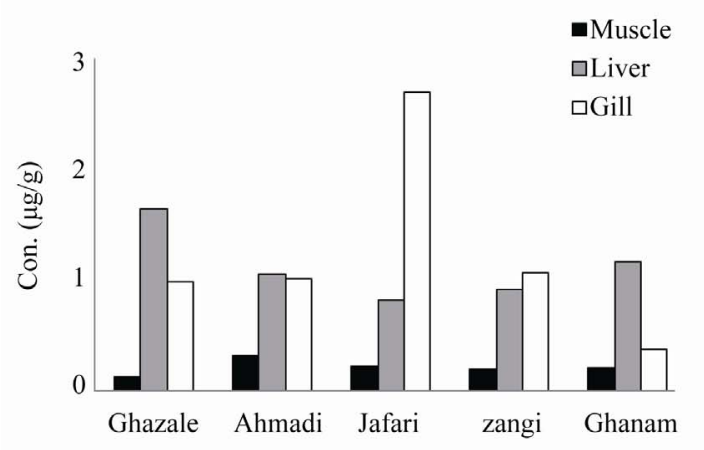

(a)

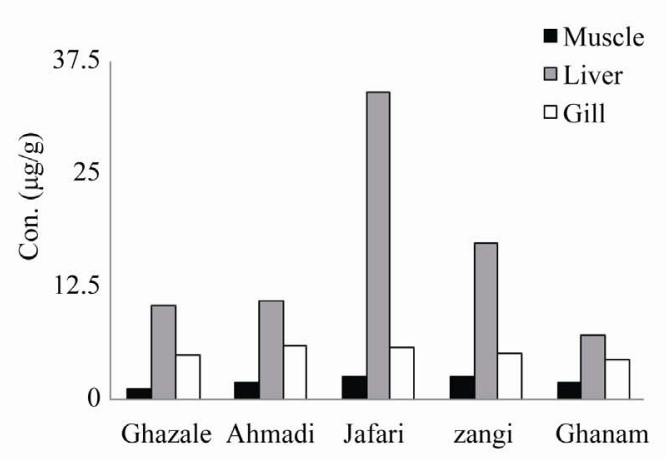

(c)
Gill is the main place for gas exchange in fish. In this organ, because of the short distance between blood and surrounding seawater, heavy metals ions may directly taken up from the passing water [31]. On the hand, it is also engaged in excretion of metals ion out of the body. Thus, the marked concentration of metals found in this tissue could be related to accumulative capacity of this organ during its role in depuration and absorption of uptaken heavy metals [9]. Another explains for finding high concentration in gill, mucous excretion by this organ. The excreted mucous has affinity to be bound with metal ions. Therefore, even when heavy metals accumulation is low in other tissues it is possible to find considerable

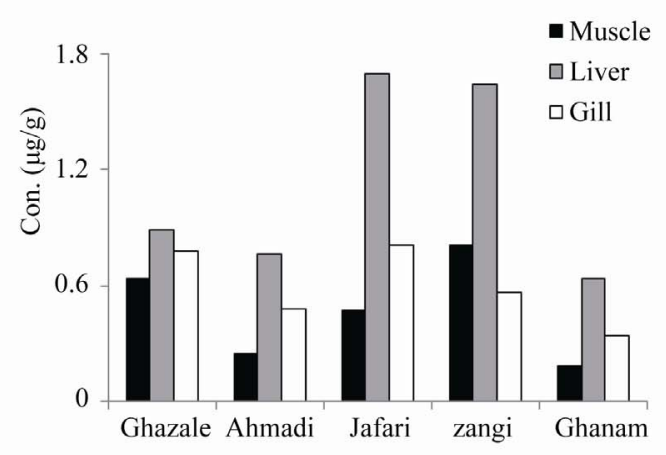

(b)

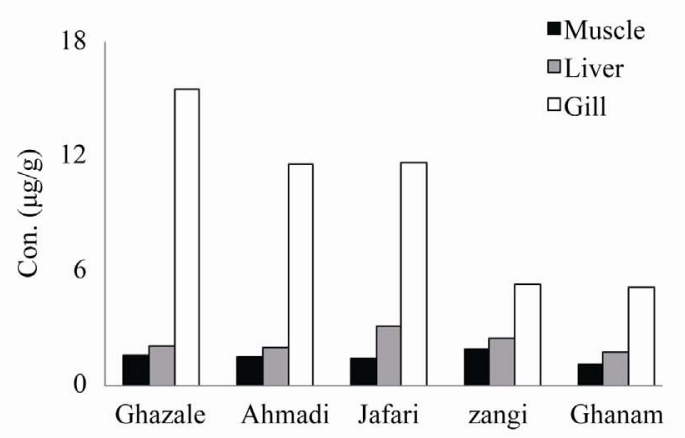

(d)

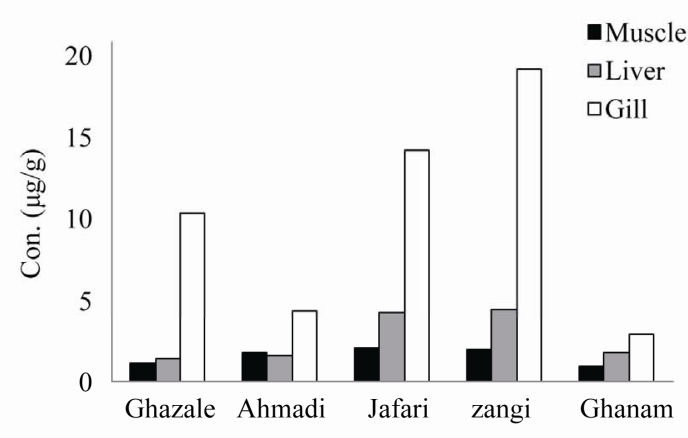

(e)

Figure 2. Heavy metals concentration in L. abu tissues; (a): Cd; (b): Co; (c): Cu; (d): Ni; (e): Pb. 
amount of metals in this part [38,39].

\subsection{Comparison with Standard and Previous Study}

Heavy metals concentration in various tissues of Mullet, L. $a b u$ from the northwest Persian Gulf is compared with some previous studies from other locations of the world (Table 5). The concentration of $\mathrm{Cd}, \mathrm{Cu}$ and $\mathrm{Ni}$ in muscle of L. $a b u$ from Musa Estuary were higher than Solea Elongate, Psettodes erumeei and Epinephelus coioides from north Persian Gulf [40] and Dicentrarchus labrax, Sparus aurata and Mugil cephalus from Tuzen Lagoon [13]. However, the concentration of $\mathrm{Cd}$ and $\mathrm{Pb}$ in present study was lower than those given for Liza ramada from
Rosario [41]. The concentration of $\mathrm{Cd}, \mathrm{Co}$ and $\mathrm{Cu}$ in the liver of Liza abu was higher than the species that studied by Dural et al., (2007). On the other hand, the level of $\mathrm{Cu}$ in the liver of L. $a b u$ from Ataturk was higher than $L$. $a b u$ that was caught from Musa Estuary. The maximum concentration of $\mathrm{Cu}, \mathrm{Ni}$ and $\mathrm{Pb}$ in gills during this study were higher than the results that reported by Dural et al., (2007) and similar to the results that reported by Karadede et al., (2004) for $\mathrm{Cu}$. The higher concentration of $\mathrm{Ni}$ and Co in L. abu from the Persian Gulf may be attributed to the strong oil pollution in the area.

Comparison of metals concentration in current study with some available standards (Table 6) showed that $\mathrm{Cd}$ concentration in the fish muscle of Khor-Ahmadi, Khor-

Table 5. Heavy metal concentration in fish tissues reported in literature $(\mu \mathrm{g} / \mathrm{g} \mathrm{dw})$.

\begin{tabular}{|c|c|c|c|c|c|c|c|c|}
\hline Tissues & Location & Species & $\mathrm{Cd}$ & Co & $\mathrm{Cu}$ & $\mathrm{Ni}$ & $\mathrm{Pb}$ & Reference \\
\hline \multirow[t]{9}{*}{ Muscle } & Musa Estuary & Liza abu & & & & & & This study \\
\hline & Persian Gulf, northern Part & Solea elongata & 0.072 & & & 6.69 & 2.43 & {$[40]$} \\
\hline & Persian Gulf, northern Part & Psettodes erumeei & 0.105 & & & 1.09 & 2.09 & [40] \\
\hline & Persian Gulf northern Part & Epinephelus coioides & 0.111 & & & 1.56 & 2.32 & {$[40]$} \\
\hline & Ataturk Dam Lake & Liza $a b u^{*}$ & & ND & 1.36 & $\mathrm{ND}$ & & [7] \\
\hline & Tuzla lagoon & Dicentrarchus labrax & 0.08 & & 0.26 & & 0.40 & \\
\hline & Tuzla lagoon & Sparus aurata & 0.10 & & 0.82 & & 2.44 & [7] \\
\hline & Tuzla lagoon & Mugil cephalus & 0.11 & & 0.47 & & 0.49 & \\
\hline & Rosario & Liza ramada & 0.9 & & 1.6 & & 3.7 & {$[41]$} \\
\hline \multicolumn{9}{|l|}{ Liver } \\
\hline & Musa Estuary & Liza abu & & & & & & This study \\
\hline & Ataturk Dam Lake & Liza $a b u^{*}$ & & ND & 267.45 & $\mathrm{ND}$ & & [7] \\
\hline & Tuzla lagoon & Dicentrarchus labrax & 0.19 & & 0.69 & & 1.72 & \\
\hline & Tuzla lagoon & Sparus aurata & 0.19 & & 2.63 & & 1.87 & {$[13]$} \\
\hline & Tuzla lagoon & Mugil cephalus & 0.21 & & 4.77 & & 2.12 & \\
\hline \multirow[t]{5}{*}{ Gill } & Musa Estuary & Liza $a b u$ & & & & & & This study \\
\hline & Ataturk Dam Lake & Liza $a b u^{*}$ & & ND & 6.27 & $\mathrm{ND}$ & & {$[7]$} \\
\hline & Tuzla lagoon & Dicentrarchus labrax & 1.12 & & 1.10 & & 3.71 & \\
\hline & Tuzla lagoon & Sparus aurata & 1.01 & & 1.94 & & 3.86 & [13] \\
\hline & Tuzla lagoon & Mugil cephalus & 1.27 & & 3.43 & & 4.54 & \\
\hline
\end{tabular}

Concentration are in $\mu \mathrm{g} / \mathrm{g}$ dry weight, except the cases are denoted with asterisk, which are in $\mu \mathrm{g} / \mathrm{g}$ wet weight. ND = Not Detect.

Table 6. Heavy metal concentration in guide line.

\begin{tabular}{|c|c|c|c|c|}
\hline Standard & $\mathrm{Cd}$ & $\mathrm{Cu}$ & $\mathrm{Pb}$ & References \\
\hline FAO, (1983) & $0.5(\mathrm{ppm})$ & $30(\mathrm{ppm})$ & $0.5(\mathrm{ppm})$ & {$[42]$} \\
\hline Turkish Guidelines $^{\mathrm{a}}$ & $0.1(\mu \mathrm{g} / \mathrm{g})$ & $20(\mu \mathrm{g} / \mathrm{g})$ & $1(\mu \mathrm{g} / \mathrm{g})$ & {$[43]$} \\
\hline Saudi Arabia & $0.5(\mu \mathrm{g} / \mathrm{g})$ & & $2(\mu \mathrm{g} / \mathrm{g})$ & {$[44]$} \\
\hline $\mathrm{EC}^{\mathrm{b}}$ & $0.05(\mu \mathrm{g} / \mathrm{g})$ & & $0.5(\mu \mathrm{g} / \mathrm{g})$ & {$[44]$} \\
\hline
\end{tabular}

\footnotetext{
${ }^{\mathrm{a}}$ Turkish Environmental Guidelines (1988). EC = European Communities.
} 
Zangi and Khor-Ghanam during the summer were below the permissible level of EC (Commission of the European Communities, 1997), on the other hand the mentioned concentration during the winter exceeded the EC limits. In addition, $\mathrm{Pb}$ concentration of fish muscle from Khor-Zangi during the winter and in Khor-Jafari during the summer was in agreement with the limits prescribed by both EC an FAO (1983).

\section{Conclusions}

Heavy metals accumulate in different tissues of mullet fish with different magnitudes. Generally, metals accumulation in muscle was lower than gills and liver. Lead and nickel mainly accumulated in gills while the main tissue for $\mathrm{Cu}$ and $\mathrm{Co}$ accumulation was liver. Fish caught from stations closed to the PETZONE and Imam Port was found to containing high level of metals in muscle, liver and gills. The results provide new information on the distribution of heavy metals in liver, gill and edible tissues of Liza abu, and indicate that the levels of some metals exceed the legal limit that designated by some health organization. The major finding of this study demonstrated that seasons play significant role in metals accumulation. Therefore, in some seasons human might be at risk of metal contamination via fish consumption but in other seasons the level of heavy metal in the fish decreases below the dangerous limits.

\section{REFERENCES}

[1] J. Burger and M. Gochfeld, "Heavy Metals in Commercial Fish in New Jersey," Environmental Research, Vol. 99, No. 3, 2005, pp. 403-412. doi:10.1016/j.envres.2005.02.001

[2] J.L. Domingo, A. Bocio, R. Mart1-Cid and J. M. Llobet, "Benefits and Risks of Fish Consumption Part II. RIBEPEIX, a Computer Program to Optimize the Balance between the Intake of Omega-3 Fatty Acids and Chemical Contaminants," Toxicology, Vol. 230, No. 2-3, 2007, pp. 227-233. doi:10.1016/j.tox.2006.11.059

[3] N. Shirai, T. Higuchi and H. Suzuki, "Analysis of Lipid Classes and the Fatty Acid Composition of the Salted Fish Roe Food Products, Ikura, Tarako, Tobiko and Kazunoko," Food Chemistry, Vol. 94, No. 1, 2006, pp. 61-67. doi:10.1016/j.foodchem.2004.10.050

[4] N. Sinn and P. R. C. Howe, "Mental Health Benefits of Omega-3 Fatty Acids May Be Mediated by Improvements in Cerebral Vascular Function," Bioscience Hypotheses, Vol. 1, No. 2, 2008, pp. 103-108. doi:10.1016/i.bihy.2008.02.003

[5] M. I. Gladyshev, N. Sushchik, O. Anishchenko and O. N. Makhutova, "Benefit-Risk Ratio of Food Fish Intake as the Source of Essential Fatty Acids vs. Heavy Metals: A Case Study of Siberian Grayling from the Yenisei River,"
Food Chemistry, Vol. 115, No. 2, 2009, pp. 545-550. doi:10.1016/j.foodchem.2008.12.062

[6] N. Tarras-Wahlberg, A. Flachier, S. N. Lane and O. Sangfors, "Environmental Impacts and Metal Exposure of Aquatic Ecosystems in Rivers Contaminated by Small Scale Gold Mining: The Puyango River Basin, Southern Ecuador," Science of Total Environment, Vol. 278, No. 1-3, 2001, pp. 239-261.

[7] H. 1. Karadede, S. A. Oymak and E. Unlu, "Heavy Metals in Mullet, Liza $a b u$, and Catfish, Silurus triostegus, from the Ataturk Dam Lake (Euphrates), Turkey," Environment International, Vol. 30, No. 2, 2004, pp. 183-188. doi:10.1016/S0160-4120(03)00169-7

[8] M. Ozmen, Z. Ayas, A. Gungordu, G. F. Ekmekci and S. Yerli, "Ecotoxicological Assessment of Water Pollution in Sariyar Dam Lake, Turkey," Ecotoxicology and Environmental Safety, Vol. 70, No. 1, 2008, pp. 163-173. doi:10.1016/j.ecoenv.2007.05.011

[9] M. H. Al-Yousuf, M. S. El-Shahawi, and S. M. Al-Ghais. "Trace Metals in Liver, Skin and Muscle of Lethrinus lentjan Fish Species in Relation to Body Length and Sex," The Science of the Total Environment, Vol. 256, No. 2-3, 2000, pp. 87-94. doi:10.1016/S0048-9697(99)00363-0

[10] A. Turkmen, M. Türkmen, Y. Tepe and I. Akyurt, "Heavy Metals in Three Commercially Valuable Fish Species from Iskenderun Bay, Northern East Mediterranean Sea, Turkey," Food Chemistry, Vol. 91, No. 1, 2005, pp. 167-172. doi:10.1016/j.foodchem.2004.08.008

[11] M. Tuzen, "Determination of Heavy Metals in Fish Samples of the Middle Black Sea (Turkey) by Graphite Furnace Atomic Absorption Spectrometry," Food Chemistry, Vol. 80, No. 1, 2003, pp. 119-123. doi:10.1016/S0308-8146(02)00264-9

[12] A. Altındag and S. Yig, "Assessment of Heavy Metal Concentrations in the Food Web of Lake Beys Ehir, Turkey," Chemosphere, Vol. 60, No. 4, 2005, pp. 552-556. doi:10.1016/j.chemosphere.2005.01.009

[13] M. Dural, M. Ziya Lugal Goksu, and A. A. Ozak. "Investigation of Heavy Metal Levels in Economically Important Fish Species Captured from the Tuzla Lagoon," Food Chemistry, Vol. 102, No. 1, 2007, pp. 415-421. doi:10.1016/i.foodchem.2006.03.001

[14] P. Grandjean, "Methylmercury Toxicity and Functional Programming," Report of Toxicology, Vol. 23, No. 3, 2007, pp. 414-420. doi:10.1016/j.reprotox.2007.03.002

[15] J. G. Dorea, "Persistent, Bioaccumulative and Toxic Substances in Fish: Human Health Considerations," Science of the Total Environment, Vol. 400, No. 1-3, 2008, pp. 93-114. doi:10.1016/j.scitotenv.2008.06.017

[16] B. L. Gulson, K. R. Mahaffey, C. W. Jameson, K. J. Mizon, M. J. Korsch, M. A. Cameron and J. A. Eisman, "Mobilization of Lead from the Skeleton during the Postnatal Period Is Larger than during Pregnancy," Journal of Laboratory and Clinical Medicine, Vol. 131, No. 4, 1998, pp. 324-329. doi:10.1016/S0022-2143(98)90182-2 
[17] M. C. Navarro, C. Perez-Sirvent, M. J. Martınez-Sanchez, J. Vidal and J. Marimon, "Lead, Cadmium and Arsenic Bioavailability in the Abandoned Mine Site of Cabezo Rajao (Murcia, SE Spain)," Chemosphere, Vol. 63, No. 3, 2006, pp. 484-489. doi:10.1016/j.chemosphere.2005.08.017

[18] M. Canli and G. Z. Atli, "The Relationships between Heavy Metal (Cd, Cr, Cu, Fe, Pb, Zn) Levels and the Size of Six Mediterranean Fish Species," Environmental Pollution, Vol. 121, No. 1, 2003, pp. 129-136. doi:10.1016/S0269-7491(02)00194-X

[19] M. Tuzen, "Toxic and Essential Trace Elemental Contents in Fish Species from the Black Sea, Turkey," Food and Chemical Toxicology, Vol. 47, No. 8, 2009, pp. 1785-1790. doi:10.1016/j.fct.2009.04.029

[20] X. Wang, T. Sato, B. Xing and S. Tao, "Health Risks of Heavy Metals to the General Public in Tianjin, China via Consumption of Vegetables and Fish," Science of the Total Environment, Vol. 350, No. 1-3, 2005, pp. 28-37. doi:10.1016/j.scitotenv.2004.09.044

[21] H. Feng, J. K. Cochran and D. J. Hirschberg, "Transport and Sources of Metal Contaminants over the Course of Tidal Cycle in the Turbidity Maximum Zone of the Hudson River Estuary," Water Research, Vol. 36, No. 3, 2002, pp. 733-743. doi:10.1016/S0043-1354(01)00268-8

[22] V. K. Mubiana, K. Vercauteren and R. Blust, "The Influence of Body Size, Condition Index and Tidal Exposure on the Variability in Metal Bioaccumulation in Mytilus edulis," Environmental Pollution, Vol. 144, No. 1, 2006, pp. 272-279. doi:10.1016/j.envpol.2005.12.017

[23] J. Aucoin, R. Blanchard, C. Billiot, C. Partridge, D. Schultz, K. Mandhare, M. J. Beck and J. N. Beck, "Trace Metals in Fish and Sediments from Lake Boeuf, Southeastern Louisiana," Microchemical Journal, Vol. 62, No. 2, 1999, pp. 299-307. doi:10.1006/mchj.1999.1735

[24] S. Eastwood and P. Couture, "Seasonal Variations in Condition and Liver Metal Concentrations of Yellow Perch (Perca flaescens) from a Metal-Contaminated Environment," Aquatic Toxicology, Vol. 58, No. 1, 2002, pp. 43-56. doi:10.1016/S0166-445X(01)00218-1

[25] D. Mendil, O. D. Uluozlu, E. Hasdemir, M. Tuzen, H. Sari and M. Suic,mez, "Determination of Trace Metal Levels in Seven Fish Species in Lakes in Tokat, Turkey," Food Chemistry, Vol. 90, No. 1-2, 2005, pp. 175-179. doi:10.1016/j.foodchem.2004.03.039

[26] T. Ahmad, N. A. Salman and N. A. Hussain, "Effects of Some Experimental Conditions on the Behaviour and Survival of Liza abu (Heckel) from Basrah, Iraq," Journal of The Faculty of Marine Science, Vol. 3, 1404H, 1983.

[27] F. Y1lmaz , N. Ozdemir, A. Demirak and A. Levent Tuna, "Heavy Metal Levels in Two Fish Species Leuciscus cephalus and Lepomis gibbosus," Food Chemistry, Vol. 100, No. 2, 2007, pp. 830-835. doi:10.1016/j.foodchem.2005.09.020

[28] A. R. M. Mohamed, N. A. Hussain, S. S. Al-Noor, F. M.
Mutlak, I. M. Al-Sudani, A. M. Mojer, A. J. Toman and M. A. Abdad, "Fish Assemblage of Restored Al-Hawizeh Marsh, Southern Iraq," Ecohydrological Processes and Sustainable Floodplain Managemen, Vol. 8, No. 2-4, 2008, pp. 375-384.

[29] S. Duquesne, L. C. Newton, L. Giusti, S. B. Marriott, H. J. Stark and D. J. Bird, "Evidence for Declining Levels of Heavy-Metals in the Severn Estuary and Bristol Channel, U.K. and Their Spatial Distribution in Sediments," Environmental Pollution, Vol. 143, No. 2, 2006, pp. 187-196. doi:10.1016/j.envpol.2005.12.002

[30] E. P. Nobi, E. Dilipan, T. Thangaradjou, K. Sivakumar and L. Kannan, "Geochemical and Geo-Statistical Assessment of Heavy Metal Concentration in the Sediments of Different Coastal Ecosystems of Andaman Islands, India," Estuarine, Coastal and Shelf Science, Vol. 87, No. 2, 2010, pp. 253-264. doi:10.1016/j.ecss.2009.12.019

[31] A. Farkas, J. Salanki and A. Specziar, "Age- and SizeSpecific Patterns of Heavy Metals in the Organs of Freshwater Fish Abramis brama L. Populating a LowContaminated Site," Water Research, Vol. 37, No. 5, 2003, pp. 959-964.

[32] J. Kojadinovic, M. Potier, M. L. Corre, R. P. Cosson and P. Bustamante, "Bioaccumulation of Trace Elements in Pelagic Fish from the Western Indian Ocean," Environmental Pollution, Vol. 146, No. 2, 2007, pp. 548-566. doi:10.1016/j.envpol.2006.07.015

[33] F. Dang and W. X. Wang, "Assessment of Tissue-Specific Accumulation and Effects of Cadmium in a Marine Fish Fed Contaminated Commercially Produced Diet," Aquatic Toxicology, Vol. 95, No. 3, 2009, pp. 248-255. doi:10.1016/j.aquatox.2009.09.013

[34] J. Kalman, I. Riba, T. A. DelValls and J. Blasco, "Comparative Toxicity of Cadmium in the Commercial Fish Species Sparus aurata and Solea senegalensis," Ecotoxicology and Environmental Safety, Vol. 73, No. 3, 2010, pp. 306-311. doi:10.1016/j.ecoenv.2009.10.013

[35] A. B. Y1lmaz, "Levels of Heavy Metals (Fe, Cu, Ni, Cr, $\mathrm{Pb}$ and $\mathrm{Zn}$ ) in Tissue of Mugil cephalus and Trachurus mediterraneus from Iskenderun Bay Turkey," Environmental Research, Vol. 92, No. 3, 2003, pp. 277-281. doi:10.1016/S0013-9351(02)00082-8

[36] L. D. Kraemer, P. G. C. Campbell and L. Hare, "Seasonal Variations in Hepatic $\mathrm{Cd}$ and $\mathrm{Cu}$ Concentrations and in the Sub-Cellular Distribution of These Metals in Juvenile Yellow Perch (Perca flavescens)," Environmental Pollution, Vol. 142, No. 2, 2006, pp. 313-325. doi:10.1016/j.envpol.2005.10.004

[37] R. Company, H. Felıcia, A. Serafim, A. J. Almeida, M. Biscoito and M. J. Bebianno, "Metal Concentrations and Metallothionein-Like Protein Levels in Deep-Sea Fishes Captured near Hydrothermal Vents in the Mid-Atlantic Ridge off Azores," Deep-Sea Research I, Vol. 57, No. 7, 2010, pp. 893-908. doi:10.1016/j.dsr.2010.02.005

[38] S. L. R. G. Junior, F. G. Araujo, M. F. Maia and S. B. A. S. Pinto, "Evaluation of Heavy Metals in Fish of the Sepetiba and Ilha Grande Bays, Rio de Janeiro, Brazil," En- 
vironmental Research Section A, Vol. 89, 2002, pp. 171-179. doi:10.1006/enrs.2002.4341

[39] J. Usero, C. Izquierdo, J. Morillo and I. Gracia, "Heavy metals in fish (Solea vulgaris, Anguilla anguilla and Liza aurata) from Salt Marshes on the Southern Atlantic Coast of Spain," Environment International, Vol. 29, No. 7, 2003, pp. 949-956. doi:10.1016/S0160-4120(03)00061-8

[40] N. Pourang, A. Nikouyan and J. H. Dennis, "Trace Element Concentrations in Fish, Surficial Sediments and Water from Northern Part of the Persian Gulf," Environmental Monitoring and Assessment, Vol. 109, No. 1-3, 2005, pp. 293-316. doi:10.1007/s10661-005-6287-9

[41] S. Franca, C. Vinagre, I. Cacador and H. N. Cabral, "Heavy Metal Concentrations in Sediment, Benthic Invertebrates and Fish in Three Salt Marsh Areas Subjected to Different Pollution Loads in the Tagus Estuary (Portugal)," Marine Pollution Bulletin, Vol. 50, 2005, pp.
993-1018. doi:10.1016/j.marpolbul.2005.06.040

[42] T. V. Sankar, A. A. Zynudheen, R. Anandan and P. G. Viswanathan Nair, "Distribution of Organochlorine Pesticides and Heavy Metal Residues in Fish and Shellfish from Calicut Region, Kerala, India," Chemosphere, Vol. 65, No. 4, 2006, pp. 583-590. doi:10.1016/j.chemosphere.2006.02.038

[43] A. Demirak, F. Yilmaz, L. Tuna and N. Ozdemir, "Heavy Metals in Water, Sediment and Tissues of Leuciscus cephalus from a Stream in Southwestern Turkey," Chemosphere, Vol. 63, No. 9, 2006, pp. 1451-1458. doi:10.1016/j.chemosphere.2005.09.033

[44] I. Al-Saleh and N. Shinwari, "Preliminary Report on the Levels of Elements in Four Fish Species from the Arabian Gulf of Saudi Arabia," Chemosphere, Vol. 48, No. 7, 2002, pp. 749-755. doi:10.1016/S0045-6535(02)00126-1 